\title{
KLASIFIKASI KELANCARAN PEMBAYARAN PINJAMAN KOPERASI DENGAN METODE DECISION TREE
}

\author{
Raka Kandayu, Wilfrida Silaban, Malik Maulana, *Elvis Sastra Ompusunggu \\ Program Studi Sistem Informasi Fakultas Teknologi dan Ilmu Komputer, Universitas Prima Indonesia \\ Sekip, Simpang Seikambing, Medan, Indonesia, 20111 \\ E-mail: *sastraelvis@gmail.com
}

\begin{abstract}
ABSTRAK- Salah satu penyebab kredit bermasalah adalah kurang telitinya pihak koperasi dalam survei dan analisis pemberian peminjaman. Oleh karena itu, analisis kredit dengan teknik data mining perlu dilakukan sehingga dapat meminimalisir nasabah terlambat membayar pinjaman serta mempersingkat waktu analisis pemberian pinjaman. Penelitian ini bertujuan untuk membuat sistem decision tree yang dapat digunakan sebagai klasifikasi nasabah peminjaman berdasarkan nilai kelancaran pembayaran pinjamannya. Pada penelitian ini atribut yang yang digunakan sebagai acuan untuk menganalisis kelacancaran pembayaran pinjaman koperasi adalah status keanggotaan, status pernikahan, pekerjaan, pendapatan, pengeluaran, jaminan, keperluan, jumlah pinjaman dan lama pinjman. Algotitma C4.5 digunakan untuk membentu decision tree dengan cara mencari nilai entropy, gain info, split info, dan gain ratio pada setiap atribut untuk menentukan atribut akar dan cabangnya.
\end{abstract}

Kata kunci : data mining, koperasi, decision tree, algoritma C4.5

\section{PENDAHULUAN}

Pertumbukan teknologi yang sangat pesat telah menciptakan kondisi kaya akan data namun dengan sedikit informasi yang dapat di ambil, data mining merupakan salah satu cara untuk mengubah data menjadi informasi yang dapat mengatasi kondisi tersebut [1]. Data mining sendiri memiliki beberapa teknik salah satunya adalah klasifikasi. Teknik klasifikasi terdiri dari beberapa metode antara lain adalah decision tree.

Decision tree adalah salah satu metode klasifikasi yang paling populer, karena mudah untuk diinterpretasi oleh manusia. Decision tree adalah model prediksi menggunakan struktur pohon atau struktur berhirarki. Konsep dari pohon keputusan adalah mengubah data menjadi decision tree dan aturan-aturan keputusan. Manfaat utama dari penggunaan decision tree adalah kemampuannya untuk membreak down proses pengambilan keputusan yang kompleks menjadi lebih simple, sehingga pengambil keputusan akan lebih menginterpretasikan solusi dari permasalahan.

Koperasi Rutan Kelas 1 Medan merupakan unit koperasi yang mempunyai kegiatan utama penyediaan jasa penyimpanan dan pinjaman dana kepada anggota koperasi dengan tujuan memajukan kesejahteraan anggota koperasi tersebut. Namun pada saat ini masih banyak nasabah yang kurang lancar dalam membayar pinjamannya dan memberikan kerugian pada koperasi rutan kelas 1 Medan, hal ini terjadi dikarnakan kurang mampunya pihak koperasi dalam menganalisa nasabah yang akan melakukan peminjaman pada koperasi rutan kelas 1 Medan.

Menurut Jajam Haerul Jaman, dkk dalam penelitiannya berjudul "Penerapan algoritma C4.5 untuk penentuan penerima beasiswa" menjelaskan bahwa data mining dengan metode decision tree dapat digunakan pada klasifikasi untuk menentukan penerima beasiswa dan Erlin Elisa dalam penelitiannya yang berjudul "Analisis dan Penerapan Algoritma C4.5 dalam Data mining untuk Mengidentifikasi Faktor- Faktor Penyebab Kecelakaan Kerja Kontruksi PT.Arupdahatu Adisesanti" menjelaskan decision tree dapat digunakan untuk mengidentifikasi faktor-faktor kecelakaan kerja, oleh sebab itu penulis beranggapan bahwa data mining dengan metode decision tree dapat digunakan pada bidang lainnnya[2][3].

Berdasarkan data yang diperoleh, maka kami membuat penelitian mengenai prediksi kelancaran pembayaran dari sebuah klasifikasi atau prediksi yang ditonjolkan dalam metode decision tree, misalnya sebuah unit Koperasi Rutan kelas 1 Medan dalam membuat sebuah sistem yang cukup akurat untuk memprediksi anggota mana yang mampu melakukan pembayaran simpan pinjam dengan lancar.

\subsection{Tujuan Penelitian}

Untuk meningkatkan ilmu pengetahuan tentang data mining dengan menggunakan metode Decision tree dan untuk membantu para karyawan koperasi untuk lebih mudah dalam prediksi kelancaran pemabayaran pinjaman anggota koperasi.

\subsection{Manfaat Penelitian}

Meningkatkan pemahaman atau menambah ilmu pengetahuan tentang data mining menggunakan algoritma C4.5, Memberikan prediksi kelancaran pembayaran pinjaman koperasi dan Mengurangi resiko pemberian pinjaman kepada anggota yang tidak lancar membayar.

\section{ISI PENELITIAN}

Dalam Penelitian ini pengklasifikasian nasabah menggunakan metode Decision tree Algoritma C4.5. Memerlukan Atribut dan nilai atribut untuk 
JUSIKOM PRIMA (Jurnal Sistem Informasi dan Ilmu Komputer Prima)

melakukan perhitungan sehingga dapat mengklasifikasikan nasabah dengan benar, yaitu Status keangotaan, Status pernikahan, Pekerjaan, pendapatan, pengeluaran, jamian keperluan, jumlah pinjaman dan lama pinjaman.

Dalam perhitungan algoritma C4.5 atribut yang digunakan ditentukan dengan cara mencari gain rasio terbesar, namun untuk mendapatkan gain rasio pertama-tama harus menghitung entropy, gain info dan split info.

\subsection{Nilai Entropy}

Cara Menghitung Entropy :

Entropy $=((-$ Total Lancar/Total Kasus $) * \log 2$ (Total Lancar/Total Kasus)+(-Total Macet/Total Kasus)*Log2(Total Macet/Total Kasus)

Tabel 2.1 Tabel Nilai Entropy

\begin{tabular}{|c|c|}
\hline Atribut & Nilai Entropy \\
\hline Total & 0,9868 \\
\hline \multicolumn{2}{|l|}{ Status Keanggotaan } \\
\hline 1. Anggota & 1. 0,7284 \\
\hline 2. Bukan Anggota & 2. 0 \\
\hline \multicolumn{2}{|l|}{ Status Pernikahan } \\
\hline 1. Menikah & 1. 0,9969 \\
\hline 2. Belum Menikah & 2. 0,9363 \\
\hline \multicolumn{2}{|l|}{ Pekerjaan } \\
\hline 1. PNS & 1. 0,8562 \\
\hline 2. Karyawan Swasta & 2. 0,9899 \\
\hline 3. Wirausaha & 3. 0,9517 \\
\hline 4. Lainnya & 4. 0,8948 \\
\hline \multicolumn{2}{|l|}{ Pendapatan } \\
\hline 1. $0-2.500 .000$ & 1. 0,9865 \\
\hline $\begin{array}{ll}2 . & 2.500 .001- \\
& 5.000 .000\end{array}$ & 2. 0,9885 \\
\hline $\begin{array}{ll}\text { 3. } & 5.000 .001- \\
& 7.500 .000\end{array}$ & 3. 0,9726 \\
\hline $\begin{array}{ll}\text { 4. } & 7.500 .001- \\
& 10.000 .000\end{array}$ & 4. 0,9709 \\
\hline 5. $10.000 .000+$ & 5. 0 \\
\hline \multicolumn{2}{|l|}{ Pengeluaran } \\
\hline 1. Kecil & 1. 0,8418 \\
\hline 2. Menengah & 2. 0,9724 \\
\hline 3. Besar & 3. 0,9986 \\
\hline \multicolumn{2}{|l|}{ Jaminan } \\
\hline 1. Surat Tanah & 1. 0,9938 \\
\hline 2. SK Kepegawaian & 2. 0,7341 \\
\hline 3. ВPKB & 3. 0,9709 \\
\hline 4. Logam Mulia & 4. 0,9725 \\
\hline 5. Tidak Ada & 5. 0,9544 \\
\hline Keperluan & \\
\hline
\end{tabular}

\begin{tabular}{|c|c|}
\hline $\begin{array}{l}\text { 1.Modal Usaha } \\
\text { 2.Pribadi }\end{array}$ & $\begin{array}{ll}\text { 1. } & 0,97 \\
\text { 2. } & 0,9912\end{array}$ \\
\hline $\begin{array}{c}\text { Jumlah Pinjaman } \\
{[1] .0-25.000 .000} \\
{[2] .25 .000 .001-} \\
50.000 .000 \\
{[3] .50 .000 .001-} \\
75.000 .000 \\
{[4] .75 .000 .001-} \\
100.000 .000 \\
{[5] .100 .000 .000+} \\
\end{array}$ & $\begin{array}{ll}\text { 1. } & 0,9964 \\
\text { 2. } & 0,9962 \\
\text { 3. } & 0,9672 \\
\text { 4. } & 0,9985 \\
\text { 5. } & 0,7601 \\
\end{array}$ \\
\hline $\begin{array}{l}\text { Lama Pinjaman } \\
\text { 1. Pendek } \\
\text { 2. Menengah }\end{array}$ & $\begin{array}{ll}\text { 1. } & 0,9998 \\
\text { 2. } & 0,982\end{array}$ \\
\hline
\end{tabular}

\subsection{Nilai Gain Info}

Setelah mengetahui Nilai Entropy dengan perhitungan Algoritma C4.5, Maka selanjutnya kita dapat mencari nilai gain info dengan cara :

Gain info = (Entropy Total) $-($ (Total Kasus pada Nilai Atribut/Total Kasus)*Entropy Nilai atribut)

Tabel 2.2 Tabel Nilai Gain Info

\begin{tabular}{|l|c|}
\hline \multicolumn{1}{|c|}{ Atribut } & Gain Info \\
\hline Status Keanggotaan & 0,4678 \\
Status Pernikahan & 0,008 \\
Pekerjaan & 0,0861 \\
Pendapatan & 0,015 \\
Pengeluaran & 0,224 \\
Jaminan & 0,0565 \\
Keperluan & 0,0012 \\
Jumlah Pinjaman & 0,0171 \\
Lama Pinjaman & 0,0062 \\
\hline
\end{tabular}

\subsection{Nilai Split Info}

Setelah mengetahui Nilai Gain Info dengan perhitungan Algoritma C4.5, Maka selanjutnya kita dapat mencari Nilai Split Info dengan cara :

Split info $=-(($ jumlah kasus nilai atribut $1 /$ total kasus* $\log 2$ (jumlah kasus nilai atribut1/total kasus)))+ (jumlah kasus nilai atributN/total kasus* $\log 2($ jumlah kasus nilai atributN/total kasus)))).

Tabel 2.3 Tabel Nilai Split Info

\begin{tabular}{|l|c|}
\hline Atribut & Nilai Split Info \\
\hline Status Keanggotaan & 0,8656 \\
Status Pernikahan & 0,8876 \\
\hline Pekerjaan & 1,7007 \\
Pendapatan & 1,5222 \\
Pengeluaran & 1,4511 \\
Jaminan & 2,0617 \\
Keperluan & 0,8415 \\
Jumlah Pinjaman & 2,0727 \\
Lama Pinjaman & 1,5650 \\
\hline
\end{tabular}


JUSIKOM PRIMA (Jurnal Sistem Informasi dan Ilmu Komputer Prima)

Vol. 5 No. 1, Agustus 2021

E-ISSN : 2580-2879

\subsection{Nilai Gain Ratio}

Setelah mengetahui Nilai Gain info dam Split Info dengan perhitungan Algoritma C4.5, Maka selanjutnya kita dapat mencari Nilai Gain Ratio dengan cara : Gain Ratio = Gain info/Split info

Tabel 2.4 Tabel Nilai Gain Ratio

\begin{tabular}{|l|c|}
\hline \multicolumn{1}{|c|}{ Atribut } & Gain Ratio \\
\hline Status Keanggotaan & 0,540485902 \\
Status Pernikahan & 0,009404223 \\
Pekerjaan & 0,05066954 \\
Pendapatan & 0,009895335 \\
Pengeluaran & 0,015450843 \\
Jaminan & 0,027418345 \\
Keperluan & 0,001494709 \\
Jumlah Pinjaman & 0,008270782 \\
Lama Pinjaman & 0,004010801 \\
\hline
\end{tabular}

Gain ratio terbesar disini terdapat pada atribut Status Keanggotaan, sehinggga atribut Status Keanggotaan di pilih sebagai atribur akar. Setelah mendapatkan atribut akar maka selanjutnya adalah menentukan atribut cabang Decision tree dengan cara yang sama ya itu ditentukan berdasarkan gain ratio tertinggi, adapun Decision tree yang terbentuk iyalah sebagai berikut :

1. Jika Status Keanggotaan (anggota) dan Pekerjaan (wirausaha) dan Pengeluaran (besar) maka Kelas adalah Macet.

2. Jika Status Keanggotaan (anggota) dan Pekerjaan (wirausaha) dan Pengeluaran (kecil) maka Kelas adalah Lancar.

3. Jika Status Keanggotaan (anggota) dan Pekerjaan (wirausaha) dan Pengeluaran (menengah) dan Keperluan (modal usaha) maka Kelas adalah Lancar.

4. Jika Status Keanggotaan (anggota) dan Pekerjaan (wirausaha) dan Pengeluaran (menengah) dan Keperluan (pribadi) maka Kelas adalah Macet.

5. Jika Status Keanggotaan (anggota) dan Pekerjaan (PNS) maka Kelas adalah Lancar.

6. Jika Status Keanggotaan (anggota) dan Pekerjaan (karyawan swasta) dan Pengeluaran (menengah) dan Jaminan (logam mulia) dan Status Pernikahan (menikah) maka Kelas adalah Macet.

7. Jika Status Keanggotaan (anggota) dan Pekerjaan (karyawan swasta) dan Pengeluaran (menengah) dan Jaminan (logam mulia) dan Status Pernikahan (belum menikah) maka Kelas adalah Lancar.

8. Jika Status Keanggotaan (anggota) dan Pekerjaan (karyawan swasta) dan Pengeluaran (menengah) dan Jaminan (surat tanah) maka Kelas adalah Lancar.

9. Jika Status Keanggotaan (anggota) dan Pekerjaan (karyawan swasta) dan Pengeluaran (menengah) dan Jaminan (BPKB) maka Kelas adalah Lancar.

10. Jika Status Keanggotaan (anggota) dan Pekerjaan (karyawan swasta) dan Pengeluaran (menengah) dan Jaminan (tidak ada) maka Kelas adalah Macet.

11. Jika Status Keanggotaan (anggota) dan Pekerjaan (karyawan swasta) dan Pengeluaran (besar) maka Kelas adalah Macet.

12. Jika Status Keanggotaan (anggota) dan Pekerjaan (karyawan swasta) dan Pengeluaran (kecil) maka Kelas adalah Lancar.

13. Jika Status Keanggotaan (anggota) dan Pekerjaan (lainnya) dan Pengeluaran (kecil) maka Kelas adalah Lancar.

14. Jika Status Keanggotaan (anggota) dan Pekerjaan (lainnya) dan Pengeluaran (besar) maka Kelas adalah Macet.

15. Jika Status Keanggotaan (anggota) dan Pekerjaan (lainnya) dan Pengeluaran (menengah) dan Jaminan (logam mulia) dan Keperluan (pribadi) maka Kelas adalah Macet.

16. Jika Status Keanggotaan (anggota) dan Pekerjaan (lainnya) dan Pengeluaran (menengah) dan Jaminan (logam mulia) dan Keperluan (modal usaha) maka Kelas adalah Lancar.

17. Jika Status Keanggotaan (anggota) dan Pekerjaan (lainnya) dan Pengeluaran (menengah) dan Jaminan (BPKB) maka Kelas adalah Macet.

18. Jika Status Keanggotaan (anggota) dan Pekerjaan (lainnya) dan Pengeluaran (menengah) dan Jaminan (surat tanah) maka Kelas adalah Lancar.

19. Jika Status Keanggotaan (anggota) dan Pekerjaan (lainnya) dan Pengeluaran (menengah) dan Jaminan (tidak ada) maka Kelas adalah Macet.

20. Jika Status Keanggotaan (bukan anggota) maka Kelas adalah Macet.

\section{KESIMPULAN}

Sitem data mining decision tree dapat memberikan kelasifikasi kelancaran pembayaran pinjaman koperasi menggunakan algoritma C4.5 dengan cara menghitung nilai entropy, gain info, split info, dan gain ratio untuk menentukan atribut akar dan cabang pada decision tree. Pada penelitian ini gain raito terbesar terdapat pada atribut status keanggotaan yaitu sebesar 0,5404 sehingga atribut status ke anggotaan di pilih menjadi atribut akar. 
JUSIKOM PRIMA (Jurnal Sistem Informasi dan Ilmu Komputer Prima)

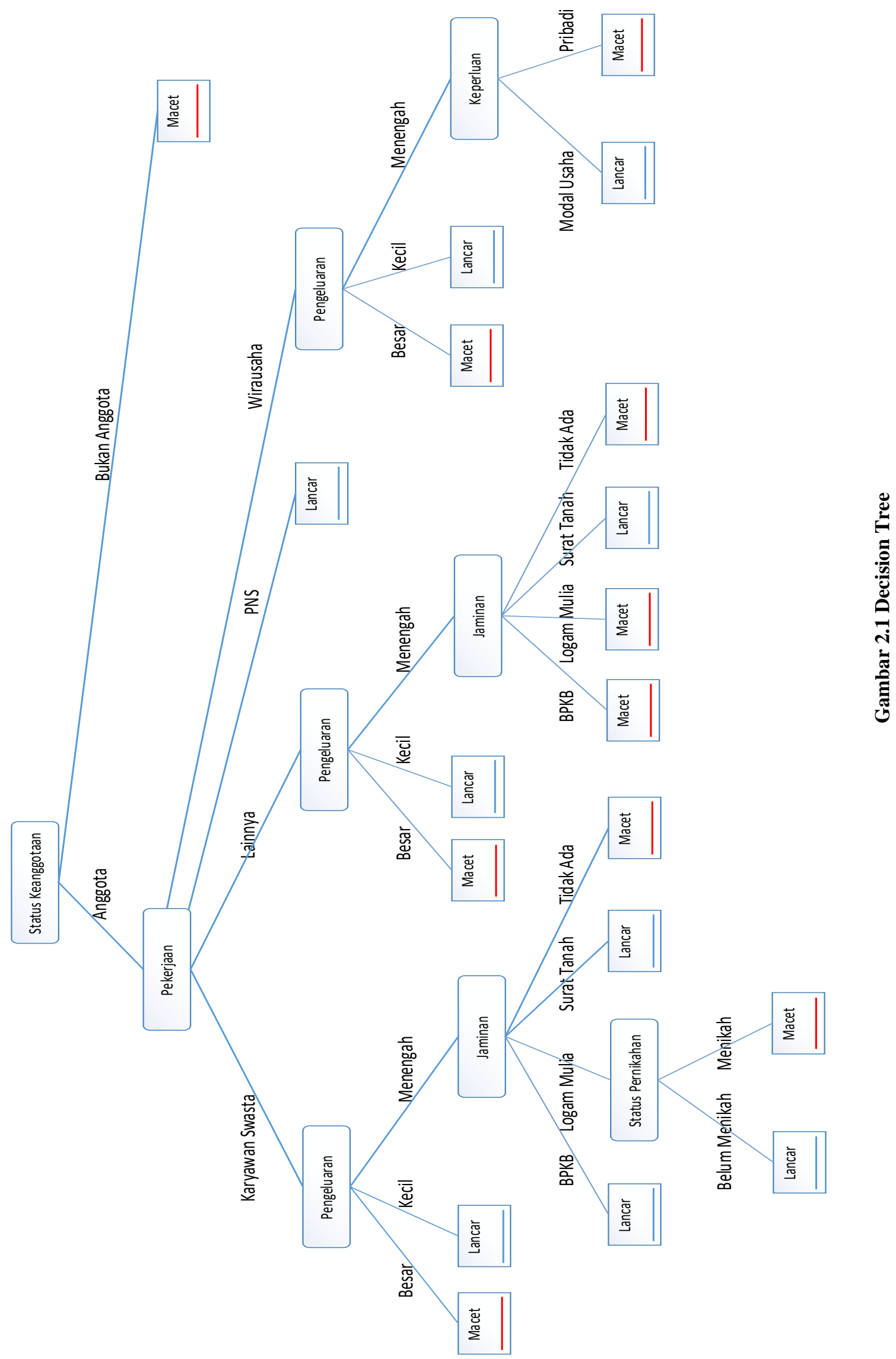


JUSIKOM PRIMA (Jurnal Sistem Informasi dan Ilmu Komputer Prima)

\section{PENUTUP}

Pengembangan dan perbaikan pada sistem klasifikasi pembayar pinjaman koperasi perlu dilakukan guna memperoleh hasil yang lebih akurat dalam mengklasifikasikan nasabah peminjma. Beberapa antara lain menggunakan metode yang lain selain decision tree C4.5, mencari faktor lain yang dapat digali dari data yang tersedi dan memperbanyak jumlah data sehingga dapat membentuk decision tree yang lebih baik.

\section{DAFTAR PUSTAKA}

[1] Nunjoko, dan K. Hendra, "Aplikasi datamining untuk memprediksi tingkat kelulusan mahasiswa menggunakan algoritma apriri di ibidarma bandar lampung," Jurnal TIM Darmajaya, vol. 02, no. 01, pp. 79-93, Mei 2016

[2]. E. Elisa, "Analisa dan penerapan algoritma c4.5 dalam data mining untuk mengidentifikasi faktor-faktor penyebab kecelakaan kerja konstruksi pt. arupadhatu adesesanti," JOIN, vol. 02 , no. 1, pp. 36-41, Juni 2017.

[3]. J. H. Jaman, dan N. I. P. Astuti, "Penerapan algoritma $\mathrm{C} 4.5$ untuk penentuan penerima beasiswa," Techno Explore, vol. 03, no. 01, pp. 25-29, April 2018.

[4]. R. Indri, "Perbandingan performasi algoritma c4.5 dan cart dalam klasifikasi data nilai mahasiswa prodi teknik komputer politeknik negeri padang," Jurnal TEKNOIF, vol. 2, No. 1, pp. 40-46, April 2014.

[5]. Informatikalogi. "Algoritma C4.5," informatikalogi, 16 Oktober 2017, [Online]. Tersedia:

https://informatikalogi.com/algoritma-c4-5. [Diakses: 20 Juli 2021]

[6]. Z. Azmi, "Decision tree berbasis algoritma untuk pengambilan keputusan," Junal Ilmiah SAINTIKOM, vol. 12 , no. 3, pp. 158164, September 2013.

[7]. P. Meilina, "Penerapan data mining dengan metode kalsifikasi menggunakan decision tree dan regresi," Jurnal Teknologi Universitas Muhammadyah jakarta, vol. 07, no. 1, pp. 11-20, Januari 2015.

[8]. T. Novianti, "Aplikasi data mining menggunakan metode decision tree untuk menampilkan laporan hasil nilai akhir mahasiswa," Jurnal Ilmiah NERO, vol. 01, no. 3, pp. 198- 203, Juli 2015.

[9]. A. Kurniawan, "Materi Tentang Data mining Lengkap,” gurupendidikan, 20 Juli 2021, [Online].Tersedia:

https://www.gurupendidikan.co.id/datamining. [Diakses: 25 Juli 2021]

[10]. N.Iriadi, "Penerapan algoritma klasifikasi data mining dalam penentuan pemberian pinjaman koperasi," jurnal paradigma, vol. 14, no. 2, pp. 120-129, September 2012.

[11]. N. Azwanti, "Analisa algoritma c4.5 untuk memprediksi penjualan motor pada pt. capella dinamik nusantara cabang muka kuning," Jurnal Ilmiah Ilmu Komputer, vol. 13, no. 1, pp. 33-38, Februari 2018. 